\title{
Preparation and evaluation of mesoporous nickel and manganese bimetallic nanocatalysts in methane dry reforming process for syngas production
}

\author{
YALDA RAMEZANI ${ }^{\mathrm{a}}$, FERESHTEH MESHKANI ${ }^{\mathrm{a}, \mathrm{b}, *}$ (D) and MEHRAN REZAEI ${ }^{\mathrm{a}, \mathrm{b}}$ \\ ${ }^{a}$ Catalyst and Advanced Materials Research Laboratory, Chemical Engineering Department, \\ Faculty of Engineering, University of Kashan, Km 6 Ravand Road, Kashan, Iran \\ ${ }^{\mathrm{b}}$ Institute of Nanoscience and Nanotechnology, University of Kashan, Kashan, Iran \\ E-mail: meshkani@kashanu.ac.ir
}

MS received 23 August 2017; revised 30 November 2017; accepted 1 December 2017; published online 1 February 2018

\begin{abstract}
In this paper, Ni-Mn catalysts supported on mesoporous nanocrystalline $\gamma-\mathrm{Al}_{2} \mathrm{O}_{3}$ were prepared and employed in carbon dioxide reforming of methane for the production of synthesis gas. The physicochemical properties of the catalysts were determined by XRD, BET, TPO and SEM techniques. The obtained results revealed that the Mn-promoted catalysts exhibited higher activity and stability and lower degree of carbon formation compared to unpromoted nickel catalyst. The catalytic results showed that the 10 (wt $\%$ ) Ni-3 (wt $\%$ ) $\mathrm{Mn} / \mathrm{Al}_{2} \mathrm{O}_{3}$ catalyst possessed the highest catalytic activity. The XRD results confirmed that the addition of Mn improves the dispersion of the active metal species on the catalyst or incorporates into the support due to a decrease in the crystallite size of $\mathrm{Ni}$ and consequently causes an increase in Ni dispersion. The 10 (wt\%) Ni-3 $(\mathrm{wt} \%) \mathrm{Mn} / \mathrm{Al}_{2} \mathrm{O}_{3}$ catalyst was stable during 20 hour on stream without any decrease in methane conversion.
\end{abstract}

Keywords. Dry reforming; Ni catalyst; syngas; nanocrystal; Mn promoter; mesoporous material.

\section{Introduction}

The increase in the concentration of $\mathrm{CH}_{4}$ and $\mathrm{CO}_{2}$ (greenhouse gases) causes a continuous increase in the surface temperature of the earth (Global warming), which is a serious atmospheric problem all over the world. These two greenhouse gases could be eliminated from the atmosphere by catalytic reactions such as dry reforming of methane. ${ }^{1,2}$

The other preference for this reaction is producing synthesis gas. Syngas, the abbreviation of synthesis gas, is a fuel gas mixture consisting primarily of hydrogen and carbon monoxide. One of the uses of this syngas is as a fuel to manufacture steam or electricity. But the main usage is in petrochemical and refining processes as a feedstock for the production of methanol, $\mathrm{H}_{2}$, liquid hydrocarbons, etc. ${ }^{3-5}$ The gasification process is applied to convert light hydrocarbons to longer hydrocarbon chains.

During the dry reforming of methane process, methane combines with carbon dioxide to generate synthetic natural gas (SNG). Dry reforming of methane is

\footnotetext{
*For correspondence
}

shown by the reaction below, and it is highly endothermic (above $800^{\circ} \mathrm{C}$ ) and requires high amount of energy to achieve high conversion of both reactants due to the strong endothermic nature of the reaction. ${ }^{6-8}$

$$
\mathrm{CH}_{4}+\mathrm{CO}_{2} \rightarrow 2 \mathrm{H}_{2}+2 \mathrm{CO} \quad \Delta H_{298}^{\circ}=247 \mathrm{~kJ} \cdot \mathrm{mol}^{-1}
$$

Until now, the wide range of mono metallic components and alloys have been used for the dry reforming reactions. ${ }^{7,9}$ Availability and low price of the nickel-based catalysts has led to the widespread use of it and also have attracted significant interest for the dry reforming reaction. ${ }^{10}$ However, the major objection to the use of $\mathrm{Ni}$-based catalysts is the rapid deactivation of these catalysts in this reaction. For instance, sulfur poisoning and carbon formation due to Boudouard or methane decomposition decrease the catalytic activity and also reverse the water gas shift reaction (RWGS) that consumes the $\mathrm{H}_{2}$, which causes the decrease in $\mathrm{H}_{2}$ selectivity. ${ }^{10-13}$ As mentioned, the coke forms mainly from two reactions ${ }^{9}$ :

The methane decomposition:

$$
\mathrm{CH}_{4} \leftrightarrow \mathrm{C}+2 \mathrm{H}_{2} \quad \Delta H_{298}^{\circ}=75 \mathrm{~kJ} \cdot \mathrm{mol}^{-1}
$$


The Boudouard reaction:

$2 \mathrm{CO} \leftrightarrow \mathrm{C}+\mathrm{CO}_{2} \quad \Delta H_{298}^{\circ}=-172 \mathrm{~kJ} \cdot \mathrm{mol}^{-1}$

These two carbon formation reactions can destroy the catalyst particles and block the reactor and deactivate the catalysts employed in dry reforming reaction. ${ }^{13}$ In addition, the RWGS reaction is ascribed by the equation below ${ }^{14-16}$ :

$\mathrm{CO}_{2}+\mathrm{H}_{2} \rightarrow \mathrm{CO}+\mathrm{H}_{2} \mathrm{O} \quad \Delta H_{298}^{\circ}=41 \mathrm{~kJ} \cdot \mathrm{mol}^{-1}$

The deposited carbon was the main reason for catalyst deactivation as indicated by the analysis in dry reforming of methane. The deposited carbon can accumulate on the catalyst surface and cover the active sites and consequently deactivate the employed catalysts. ${ }^{5}$ To suppress carbon formation over Ni-based catalysts, many attempts have been made. ${ }^{17-22}$

Using the bimetallic catalysts could be a good option for enhancing activity and stability and also inhibiting coke formation in dry reforming, which could be attributed to the synergic interactions between the metals. ${ }^{11,12}$ Choi and co-workers ${ }^{23}$ investigated the promotion effect of second metals such as $\mathrm{Mn}, \mathrm{Ti}, \mathrm{Mo}$, $\mathrm{Co}, \mathrm{Zr}, \mathrm{Cu}, \mathrm{Sr}$ and $\mathrm{Ag}$ on $\mathrm{Ni} / \mathrm{Al}_{2} \mathrm{O}_{3}$ catalysts. It was found that the modified $\mathrm{Ni}-\mathrm{Co} / \mathrm{Al}_{2} \mathrm{O}_{3}, \mathrm{Ni}-\mathrm{Cu} / \mathrm{Al}_{2} \mathrm{O}_{3}$ and $\mathrm{Ni}-\mathrm{Zr} / \mathrm{Al}_{2} \mathrm{O}_{3}$ catalysts are non-resistant in coke formation but had better performance in activity. Although the Mn-promoted catalyst showed a remarkable reduction in coke deposition but it sacrificed the catalytic activity. ${ }^{10,23,24}$ Seok $^{24}$ reported that the addition of $\mathrm{Mn}$ to $\mathrm{Ni} / \mathrm{Al}_{2} \mathrm{O}_{3}$ catalysts decreased the amount of deposited carbon in dry reforming reaction. The $\mathrm{Ni} / \mathrm{MnOx} / \mathrm{MnAl}_{2}$ $\mathrm{O}_{4}$ catalyst prepared by a coprecipitated method exhibited higher resistance against carbon formation and higher catalytic stability than the same catalyst prepared by impregnation method. ${ }^{10,24}$ Borowiecki et al. ${ }^{25}$ reported that the addition of $\mathrm{Mo}$ to $\mathrm{Ni} / \mathrm{Al}_{2} \mathrm{O}_{3}$ catalysts decreased the rate of deactivation in reforming reaction. They also showed that the addition of molybdenum as promoter significantly reduced the carbon formation and improved the activity of catalysts in steam reforming of methane. ${ }^{12,25}$ Quincocess et al., ${ }^{5}$ showed that the addition of molybdenum to nickel catalyst increased the interaction between the catalyst support and nickel, and also inhibited the growth of Ni particles.

Castro Luna and Iriarte ${ }^{4}$ reported the positive effects of different promoters ( $\mathrm{Mn}, \mathrm{K}, \mathrm{Ca}$ and $\mathrm{Sn}$ ) on the catalytic performance of the $\mathrm{Ni} / \mathrm{Al}_{2} \mathrm{O}_{3}$ catalyst. The results showed that the addition of $\mathrm{Mn}, \mathrm{Sn}$ and Ca caused a significant decrease in catalytic activity and a dramatic increase in carbon formation. Alumina and $\mathrm{SiO}_{2}$ have been considered as support for Ni-based catalysts due to high availability and high specific surface. ${ }^{2}$ In particular, mesoporous $\mathrm{Al}_{2} \mathrm{O}_{3}$ supported $\mathrm{Ni}$ catalysts exhibited excellent catalytic performance for the dry reforming reaction. ${ }^{26}$

In this paper, the effect of $\mathrm{Mn}$ promoter on the structural and catalytic properties of nickel catalysts supported on mesoporous nanocrystalline alumina is reported. In addition, the coke formation was studied over the promoted catalysts to investigate the inhibiting effect of Mn promoter on carbon formation. ${ }^{10,24,27}$

\section{Experimental}

\subsection{Sample preparation}

The $\gamma-\mathrm{Al}_{2} \mathrm{O}_{3}$ support was prepared by the sol-gel method using the aluminium tri-isopropylate as $\mathrm{Al}$ precursor based on the method described in our previous work. ${ }^{9}$ In this solgel method, the aluminium precursor was hydrolyzed (at $80-85{ }^{\circ} \mathrm{C}$ for $1 \mathrm{~h}$ ) in distilled water. After this step, the nitric acid $\left(\mathrm{HNO}_{3}\right.$ to $\mathrm{Al}$ molar ratio $\left.=1: 1\right)$ was added to the prepared solution to obtain the sol after aging the obtained mixture at $98{ }^{\circ} \mathrm{C}$ for $12 \mathrm{~h}$. For gel formation, the prepared sol was maintained at $98{ }^{\circ} \mathrm{C}$ for $2 \mathrm{~h}$ in the atmosphere. Then the prepared gel was dried at $80^{\circ} \mathrm{C}$ and calcined at $600{ }^{\circ} \mathrm{C}$ for $4 \mathrm{~h}$. The catalysts with $10 \mathrm{wt} \% \mathrm{Ni}$ and various $\mathrm{Mn}$ contents were prepared by wet impregnation method. For this purpose, the catalyst support ( $\gamma$-alumina) was impregnated with an aqueous solution of $\mathrm{Mn}\left(\mathrm{NO}_{3}\right)_{2} \cdot 4 \mathrm{H}_{2} \mathrm{O}$ with appropriate concentration at room temperature to obtain the desired content of Mn. After impregnation, the suspension was dried at $80^{\circ} \mathrm{C}$ overnight and calcined at $450^{\circ} \mathrm{C}$ in air. After that, the promoted support was impregnated by an aqueous solution of $\mathrm{Ni}\left(\mathrm{NO}_{3}\right)_{2} \cdot 6 \mathrm{H}_{2} \mathrm{O}$ with the same method described above and calcined at $500{ }^{\circ} \mathrm{C}$ for $4 \mathrm{~h}$.

$\mathrm{Ni}-\mathrm{Mn}$ bimetallic catalyst was also prepared by a coprecipitation method. The metal salt precursors with desired contents $\left(\mathrm{Ni}\left(\mathrm{NO}_{3}\right)_{2} \cdot 6 \mathrm{H}_{2} \mathrm{O}, \mathrm{Mn}\left(\mathrm{NO}_{3}\right)_{2} \cdot 4 \mathrm{H}_{2} \mathrm{O}\right.$ and $\mathrm{Al}\left(\mathrm{NO}_{3}\right)_{3}$. $9 \mathrm{H}_{2} \mathrm{O}$ ) were dissolved in deionized water under stirring. Then, an aqueous solution of $\mathrm{NaOH}$ was added dropwise to the prepared solution at room temperature and the $\mathrm{pH}$ was adjusted to 11 . The prepared suspension was filtered, washed and dried at $85{ }^{\circ} \mathrm{C}$ overnight and calcined at $500{ }^{\circ} \mathrm{C}$ for $4 \mathrm{~h}$.

\subsection{Characterization}

The BET surface area, pore volume and average pore diameter of the catalysts were determined via $\mathrm{N}_{2}$ adsorption at boiling temperature of liquid nitrogen at $-196{ }^{\circ} \mathrm{C}$ using a BELSORP Mini II analyzer. The pore size distribution was calculated from the desorption branch of the isotherm by the Barrett-Joyner-Halenda (BJH) method. The crystal structures of the prepared samples were obtained using an X-Ray diffractometer (PANalytical X'Pert-Pro) by a Ni filter in the range of 
Table 1. Textural properties of various samples.

\begin{tabular}{|c|c|c|c|c|c|c|}
\hline \multirow[t]{2}{*}{ Catalyst } & \multicolumn{2}{|c|}{$\begin{array}{l}\text { Active metal } \\
\text { composition (wt } \%)\end{array}$} & \multirow[t]{2}{*}{$S_{\mathrm{BET}}\left(\mathrm{m}^{2} \mathrm{~g}^{-1}\right)$} & \multirow[t]{2}{*}{$\begin{array}{l}\text { Pore volume } \\
\left(\mathrm{cm}^{3} \mathrm{~g}^{-1}\right)\end{array}$} & \multirow[t]{2}{*}{$\begin{array}{l}\text { Average pore } \\
\text { diameter (nm) }\end{array}$} & \multirow[t]{2}{*}{$\begin{array}{l}\text { Crystal size } \\
(\mathrm{nm})\end{array}$} \\
\hline & $\mathrm{Ni}$ & $\mathrm{Mn}$ & & & & \\
\hline $10 \mathrm{Ni} 1 \mathrm{Mn}$ & 10 & 1 & 167.1 & 0.4 & 10.2 & 5.8 \\
\hline $10 \mathrm{Ni} 3 \mathrm{Mn}$ & 10 & 3 & 166.3 & 0.4 & 10.6 & 7.8 \\
\hline $10 \mathrm{Ni} 5 \mathrm{Mn}$ & 10 & 5 & 150.1 & 0.4 & 10.1 & 8.7 \\
\hline $10 \mathrm{Ni}$ & 10 & 0 & 171.7 & 0.5 & 10.6 & - \\
\hline $5 \mathrm{Mn}$ & 0 & 5 & 182.9 & 0.5 & 10.8 & - \\
\hline$\gamma$-Alumina & 0 & 0 & 185.9 & 0.5 & 10.7 & - \\
\hline
\end{tabular}

$2 \theta=10-80^{\circ}$ using the $\mathrm{Cu}-\mathrm{K} \alpha$ monochromatized radiation source. The reduction properties of the calcined catalysts were evaluated by the temperature programmed reduction (TPR) analysis with a Micromeritics chemisorb 2750 instrument. In this analysis, a specific amount of catalyst (100 $\mathrm{mg}$ pretreated under an inert atmosphere (Ar) at $200{ }^{\circ} \mathrm{C}$ for $1 \mathrm{~h}$ ) was subjected to a heat treatment $\left(10{ }^{\circ} \mathrm{C} / \mathrm{min}\right)$, while a reducing gas flow $(30 \mathrm{~mL} / \mathrm{min})$ containing a mixture of $\mathrm{H}_{2}$ : $\mathrm{Ar}$ (10:90) was passed over the catalyst surface. A thermal conductivity detector (TCD) measured the $\mathrm{H}_{2}$ consumption during the reduction process. Temperature-programmed oxidation (TPO) analysis of the spent catalysts was performed with a similar instrument as described for TPR analysis. In this analysis, a gas flow $(30 \mathrm{~mL} / \mathrm{min})$ of $\mathrm{O}_{2}: \mathrm{He}(5: 95)$ mixture was passed over $25 \mathrm{mg}$ of the spent catalyst and the temperature increased at a heating rate of $10^{\circ} \mathrm{C} \mathrm{min}^{-1}$ up to $800^{\circ} \mathrm{C}$. A VEGA TESCAN microscope operated at $30 \mathrm{kV}$ was used for studying the morphology the prepared samples.

\subsection{Catalytic evaluation}

A quartz tubular fixed-bed reactor was used for determining the catalytic performance of the prepared catalysts under atmospheric pressure. The calcined catalyst powders were pressed, crushed and sieved to obtain catalyst particles with specified sizes. The quartz reactor was loaded with 200 $\mathrm{mg}$ of the catalyst particles (35-60 mesh) and the catalysts were reduced in situ at $600{ }^{\circ} \mathrm{C}$ for $4 \mathrm{~h}$ in an $\mathrm{H}_{2}$ stream $(25$ $\mathrm{mL} / \mathrm{min}$ ). Later, the reactant gas mixture containing methane and carbon dioxide with the desired ratio was introduced into the reactor, and the activity tests were carried out at various reaction temperatures in the range of $550-700^{\circ} \mathrm{C}$. The mole percent of different components in reactants and products was determined using a gas chromatograph equipped with a TCD and a Carboxen 1000 column. The conversion of methane and carbon dioxide and the yields of hydrogen and carbon monoxide were obtained from the following equations ${ }^{14,28}$ :

Methane conversion:

$X_{\mathrm{CH}_{4}}=\frac{\mathrm{CH}_{4(\text { in })}-\mathrm{CH}_{4(\text { out })}}{\mathrm{CH}_{4(\text { in })}} \times 100 \%$
Carbon dioxide conversion:

$X_{\mathrm{CO}_{2}}=\frac{\mathrm{CO}_{2(\text { in })}-\mathrm{CO}_{2(\text { out })}}{\mathrm{CO}_{2(\text { in })}} \times 100 \%$

Hydrogen yield: $\frac{\mathrm{H}_{2(\text { out })}}{2 \mathrm{CH}_{4(\text { in })}} \times 100 \%$

\section{Results and Discussion}

\subsection{Physicochemical properties}

The results of BET analysis are summarized in Table 1. It is seen that the catalyst support exhibited high specific surface area and pore volume with a small average pore size around $10 \mathrm{~nm}$. The addition of nickel to catalyst support decreased the BET area and pore volume due to partial blockage of the pores of the alumina with $\mathrm{NiO}$ particles. ${ }^{4,15,29}$ Furthermore, the addition of Mn promoter, increasing in its content caused decrease in BET area and pore volume. However, the addition of nickel and Mn does not have a significant effect on the average pore size. The lowest BET area was observed for the $10 \mathrm{Ni}-5 \mathrm{Mn} / \mathrm{Al}_{2} \mathrm{O}_{3}$ catalyst, due to the highest amount of nickel and $\mathrm{Mn}$ promoter. The $\mathrm{Mn} / \mathrm{Al}_{2} \mathrm{O}_{3}$ catalyst also exhibited high specific surface area and pore volume with small pore size, which are close to those observed for $\mathrm{Al}_{2} \mathrm{O}_{3}$.

The $\mathrm{N}_{2}$ adsorption/desorption isotherms and pore size distributions are shown in Figure 1a and b, respectively. According to the IUPAC classification, the isotherms of all catalysts can be categorized as type IV with $\mathrm{H}_{2}$ hysteresis loops, which is related to mesoporous materials with cylindrical shaped pores. ${ }^{16,29}$

As the size of pores increased, the hysteresis loop shifted to the right in the diagram. At high relative pressures, nitrogen adsorption occurs in larger mesopores. It is seen that the type of the isotherm of the alumina support was not affected by the addition of $\mathrm{Ni}$ and $\mathrm{Mn}$.

Pore size distributions of all catalysts are presented in Figure 1b. All catalysts show a narrow single modal 

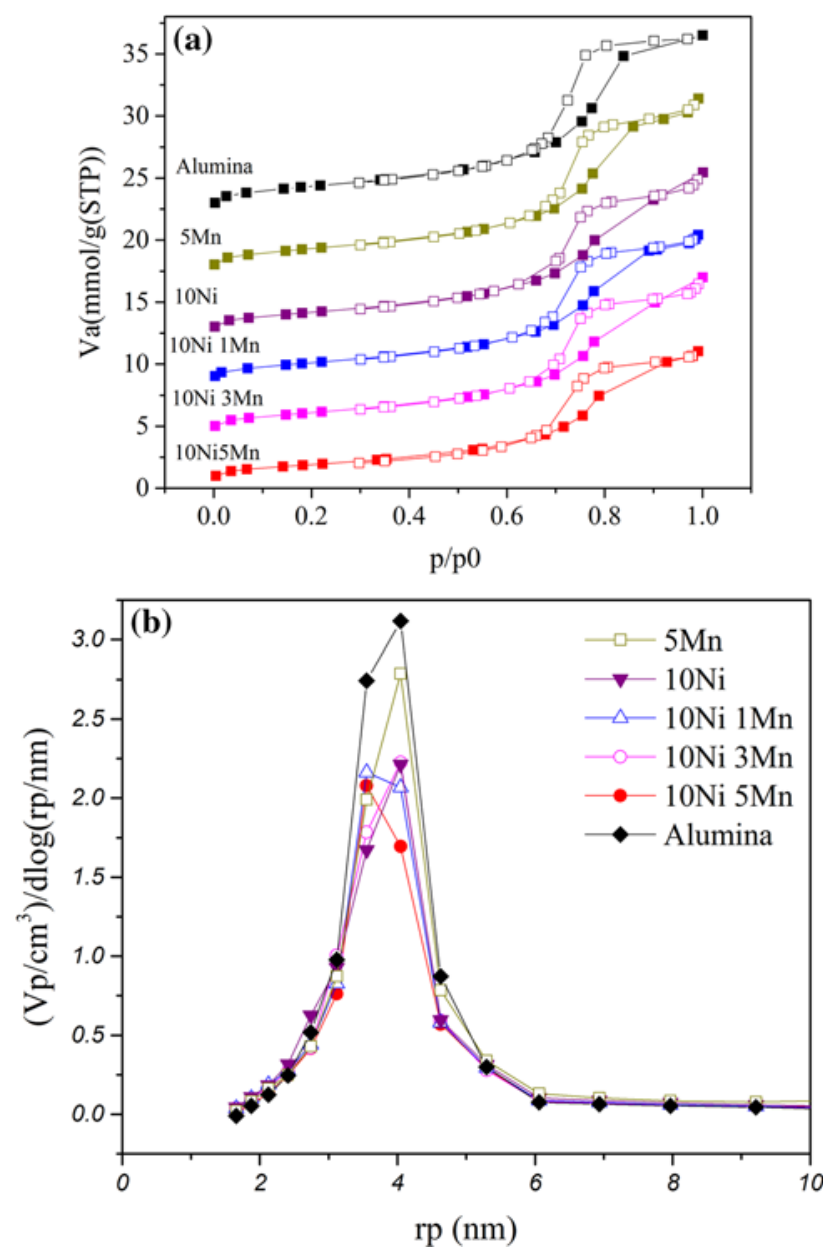

Figure 1. (a) $\mathrm{N}_{2}$ adsorption/desorption isotherms and (b) pore size distributions of the prepared samples.

pore size distribution with a maximum centered around $4 \mathrm{~nm}$ (pore radius). The observed pore radius of all catalysts was located between 2-6 nm. Such mesoporous structures played a significant role for a metallic catalyst to prevent the agglomeration of active phase through the confined effect, which restricts the growth of Ni crystallites during high temperature reaction. ${ }^{29}$

$\mathrm{X}$-ray diffraction analysis was used for identification of bulk phase features of the Ni-Mn bimetallic supported catalysts. The XRD patterns of the calcined $\mathrm{Ni}-\mathrm{Mn} / \mathrm{Al}_{2} \mathrm{O}_{3}$ catalysts with different contents of $\mathrm{Mn}$ are shown in Figure 2.

The characteristic diffractions at $37^{\circ}, 45^{\circ}$ and $67^{\circ}$ are corresponding to the spinel-like structure $\mathrm{NiAl}_{2} \mathrm{O}_{4}$ (JCPDS Card No $=077-1877$ ) phase that has a coincidence with $\gamma-\mathrm{Al}_{2} \mathrm{O}_{3}$ (JCPDS Card No $=010-0425$ ) phase. The peaks at $37^{\circ}, 43^{\circ}$ and $63^{\circ}$ are related to the $\mathrm{NiO}$ (JCPDS Card No $=073-1519$ ) phase. The low intensity of these peaks can be related to the low percentage of this phase and it may overlap with other peaks due to the same particle size..$^{2,14,17,28}$
There are two new diffraction peaks observed in the XRD pattern of $10 \mathrm{Ni} 5 \mathrm{Mn} / \gamma-\mathrm{Al}_{2} \mathrm{O}_{3}$ and $5 \mathrm{Mn} / \mathrm{Al}_{2} \mathrm{O}_{3}$ catalysts. The first peak at $28.7^{\circ}$ and the second one at $56.9^{\circ}$ are attributed to the formation of $\mathrm{MnO}_{2}$ solid phases. It displays the $\mathrm{MnO}_{2}$ species afforded through the catalyst construction. According to the JCPDS Code No (004-0779), the $\mathrm{MnO}_{2}$ phase is a tetragonal crystalline phase. ${ }^{2,9,30}$ The intensity of $\mathrm{MnO}_{2}$ diffraction patterns differs and increases with the increase in $\mathrm{Mn}$ content. Also at the high amount of Mn promoter, the intensity of $\mathrm{NiO}$ and $\mathrm{NiAl}_{2} \mathrm{O}_{4}$ phases decreased, indicating that $\mathrm{Mn}$ improves the dispersion of the active metal species on the catalyst or incorporates into the support due to a decrease in Ni crystallite size and consequently causes an increase in $\mathrm{Ni}$ dispersion. ${ }^{31}$ The other reason can be the competition formation of crystalline phases like $\mathrm{NiMn}_{2} \mathrm{O}_{4}$ or even amorphous phase of $\mathrm{Mn}-\mathrm{Ni}$. The crystalline $\mathrm{NiMn}_{2} \mathrm{O}_{4}$ phase was observed at $2 \theta=35^{\circ}, 43^{\circ}, 57^{\circ}$ and $62^{\circ}$ (Reference code No $=001-1110)$ and overlaid with the $\mathrm{MnO}_{2}$ phase of $\mathrm{Mn}$.

Some other phases like $\mathrm{MnAl}_{2} \mathrm{O}_{4}$ are not recognized because these species need a high temperature to form while the calcination temperature of these samples was $600{ }^{\circ} \mathrm{C} .{ }^{2,9,17}$ The active metal crystallite size was determined using the Scherrer equation and the results are reported in Table 1.

$D=\frac{R \times \lambda}{\beta \times \cos \theta}$

In this equation, $\mathrm{D}$ is the active metal particle size, $\mathrm{R}$ is the Scherrer constant (0.89), $\lambda$ is the wavelength of $X$ ray $(1.5408 \AA$ ), $\theta$ is the diffraction angle, and $\beta$ is the line broadening at half the maximum intensity (radian). The results showed that increase in Mn content increased the $\mathrm{NiO}$ crystallite size. ${ }^{16}$

Hydrogen temperature-programmed reduction $\left(\mathrm{H}_{2}\right.$-TPR) experiments were applied to investigate the reducibility of the catalysts. TPR analysis is a technique for the characterization of solid components and is used to find the most efficient reduction conditions. In this experiment, an oxidized catalyst precursor is submitted to a programmed temperature rise while a reducing gas mixture flows over it.

The TPR profiles of the calcined catalysts are shown in Figure 3. The peak temperature of the TPR profile usually indicates the combined status of the active metals and the support.

The TPR analysis showed the presence of several reduction peaks at various temperatures. For the $\mathrm{Ni} / \mathrm{Al}_{2} \mathrm{O}_{3}$ catalyst, the first small reduction peak at around $480{ }^{\circ} \mathrm{C}$ is related to the reduction of nickel oxide with weak interaction with catalyst support. The 


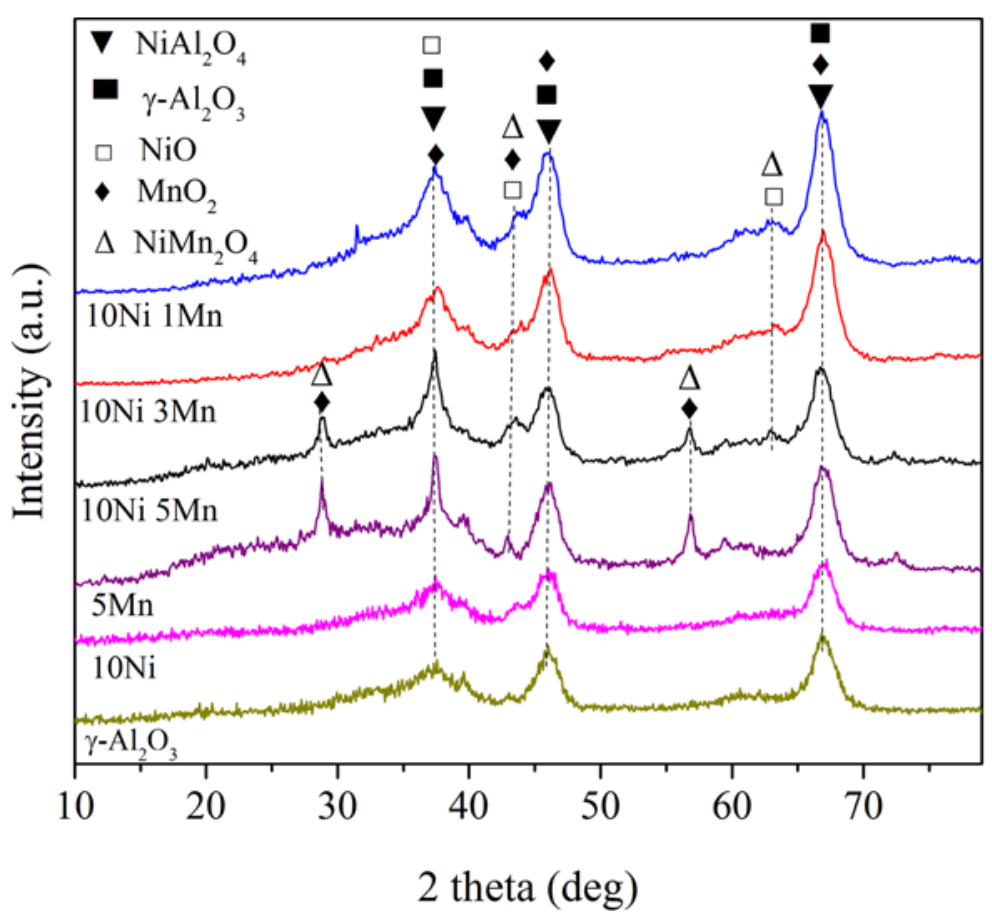

Figure 2. XRD patterns of Ni-Mn/ $/ \mathrm{Al}_{2} \mathrm{O}_{3}$ catalysts with different loadings.

main reduction peak observed at $650{ }^{\circ} \mathrm{C}$ is related to nickel oxide with strong interaction with $\mathrm{Al}_{2} \mathrm{O}_{3}$ and the shoulder peak at $800^{\circ} \mathrm{C}$ is assigned to the reduction of nickel aluminate. It seems that the addition of $\mathrm{Mn}$ promoter shifted the $\mathrm{T}_{\max }$ of the first and second reduction peaks to lower temperatures. For the $10 \mathrm{Ni}-1 \mathrm{Mn} / \mathrm{Al}_{2} \mathrm{O}_{3}$ catalyst, no peaks were observed for reduction of manganese oxide, due to the low content of that. However, for the catalysts with Mn content higher than $1 \mathrm{wt} \%$, two reduction peaks appeared at $350{ }^{\circ} \mathrm{C}-450{ }^{\circ} \mathrm{C}$ were related to the reduction of different species of manganese oxide. In $10 \mathrm{Ni}-3 \mathrm{Mn} / \mathrm{Al}_{2} \mathrm{O}_{3}$ catalyst the first reduction peak at $300{ }^{\circ} \mathrm{C}$ is associated with the reduction of $\mathrm{MnO}_{2}$ to $\mathrm{Mn}_{2} \mathrm{O}_{3}$ and the second reduction peak at a higher temperature $\left(350{ }^{\circ} \mathrm{C}\right)$ is related to the reduction of $\mathrm{Mn}_{2} \mathrm{O}_{3}$ to $\mathrm{MnO}$. For better understanding, the TPR profile of the $5 \mathrm{Mn} / \mathrm{Al}_{2} \mathrm{O}_{3}$ catalyst is also shown in Figure 3. As can be seen, two reduction peaks were observed at $300{ }^{\circ} \mathrm{C}$ and $400{ }^{\circ} \mathrm{C}$, which are related to the reduction of $\mathrm{MnO}_{2}$ to $\mathrm{Mn}_{2} \mathrm{O}_{3}$ and $\mathrm{Mn}_{2} \mathrm{O}_{3}$ to $\mathrm{MnO}$, respectively. Increase in $\mathrm{Mn}$ content intensified the peaks related to the reduction of manganese oxide species. $3,14,16,27,28,32,33$

\subsection{Catalyst performance}

As indicated in Figure 4a and b with an increase in the reaction temperature, the conversion of $\mathrm{CH}_{4}$ and $\mathrm{CO}_{2}$ increased, because of the endothermic nature of methane reforming with carbon dioxide.

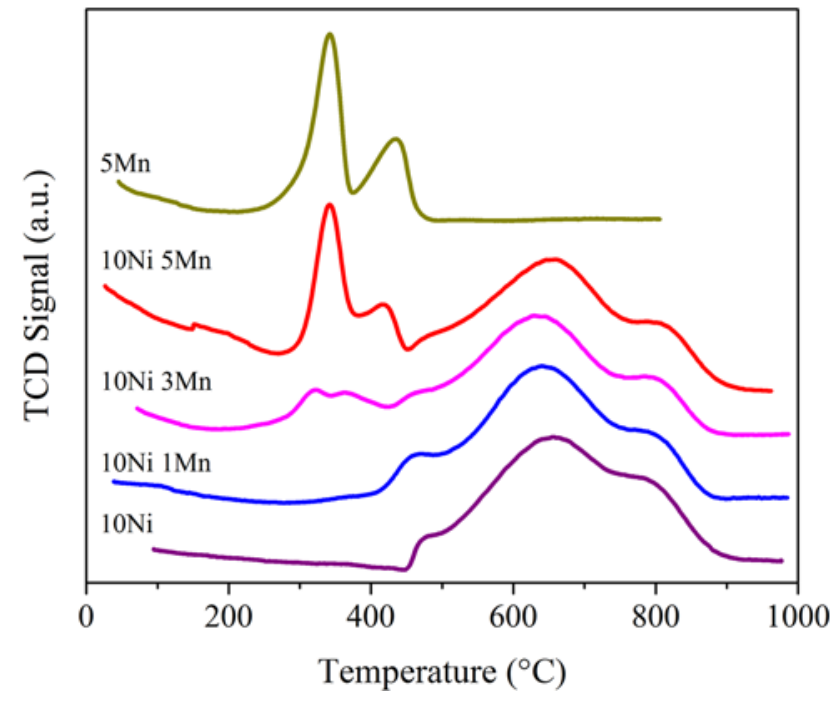

Figure 3. TPR profiles of $\mathrm{Ni}-\mathrm{Mn} / \mathrm{Al}_{2} \mathrm{O}_{3}$ catalysts.

It is also obvious that the conversion of $\mathrm{CO}_{2}$ is higher than that of $\mathrm{CH}_{4}$ on the unpromoted and promoted catalysts due to the reverse water-gas shift reaction.

To investigate the catalytic performance of the bimetallic catalysts, the catalytic results of single-metal catalysts are also shown in Figure $4 \mathrm{a}$ and b. It is seen that the addition of $\mathrm{Mn}$ as second metal influences the reactants conversion, specifically the methane conversion. This could be due to the revenue of the catalyst in the reaction. The procedure of the main reaction demonstrates that the methane molecules decomposed on the 

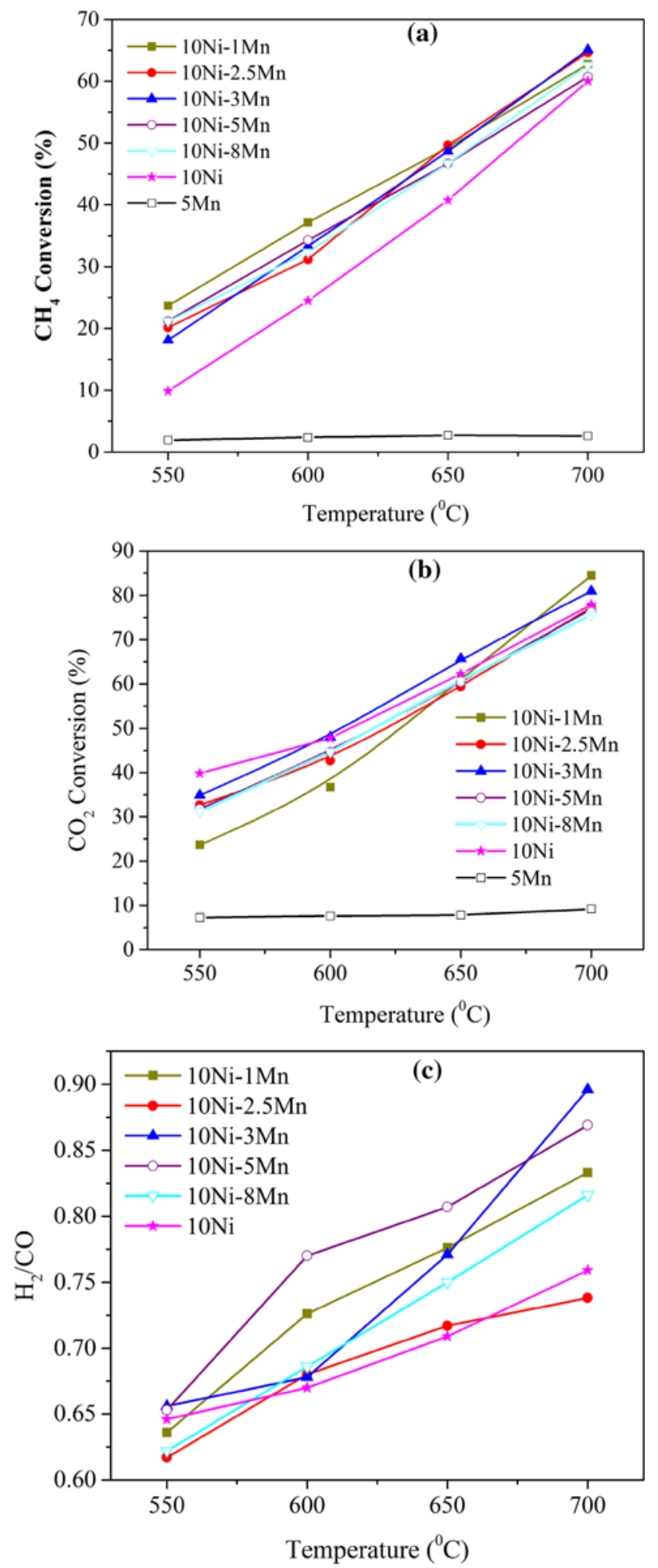

Figure 4. (a) $\mathrm{CH}_{4}$ conversion; (b) $\mathrm{CO}_{2}$ conversion; and (c) $\mathrm{H}_{2} / \mathrm{CO}$ ratio. Reaction conditions: $\mathrm{CH}_{4} / \mathrm{CO}_{2}=1 / 1, \mathrm{GHSV}=12,000\left(\mathrm{~mL} / \mathrm{h} \cdot \mathrm{g}_{\text {cat }}\right)$.

surface of nickel and carbon dioxide molecules on the support. Mn addition causes the significant structural influences on the catalyst which enhanced the $\mathrm{NiO}$ dispersion and the formation of $\mathrm{NiMn}_{2} \mathrm{O}_{4}$ resulting in the
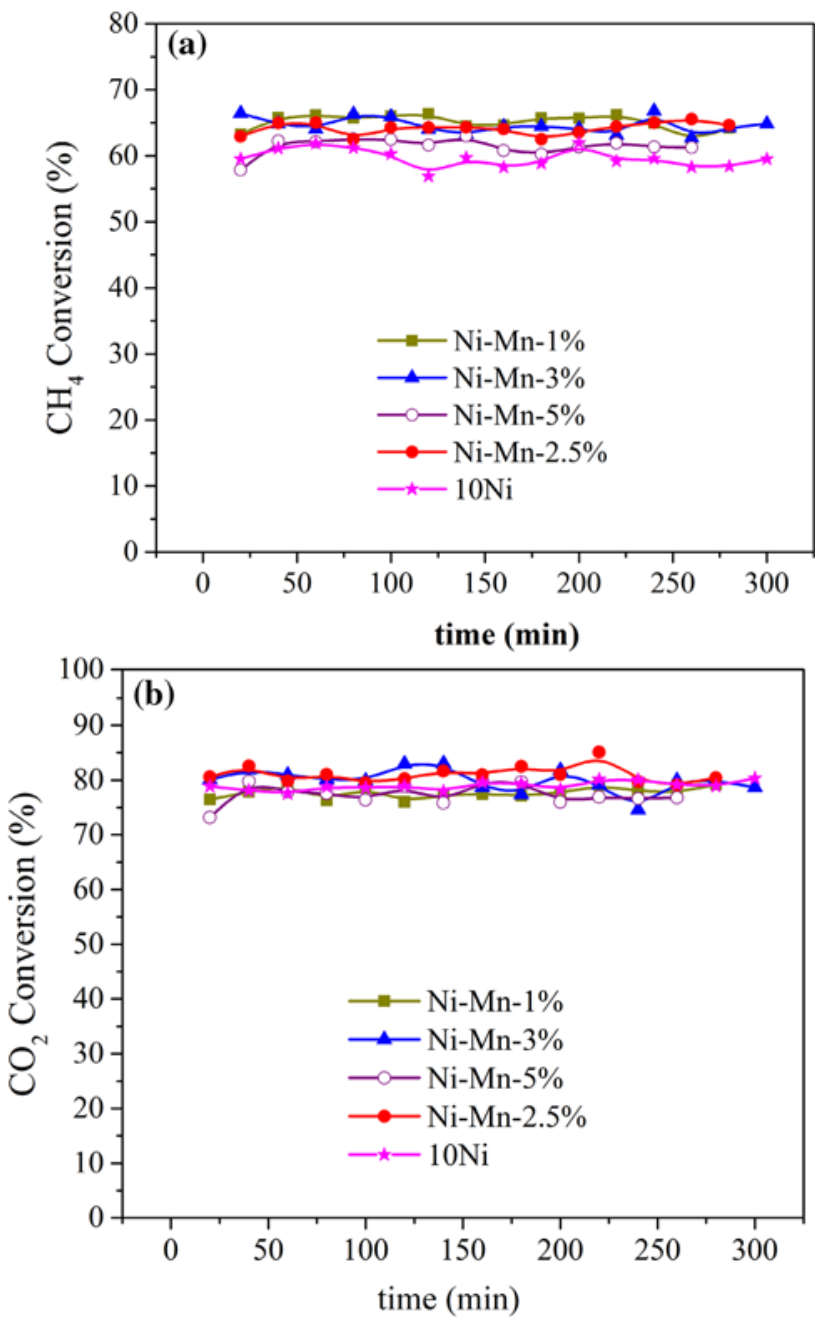

Figure 5. Short time stability of $10 \mathrm{Ni} 3 \mathrm{Mn} / \mathrm{Al}_{2} \mathrm{O}_{3}$ catalysts with various Mn loadings. (a) Methane conversion, (b) carbon dioxide conversion. Reaction conditions: $\mathrm{CH}_{4}: \mathrm{CO}_{2}=1: 1$, $\mathrm{T}=700{ }^{\circ} \mathrm{C}$ and $\mathrm{GHSV}=12000 \mathrm{~mL} /\left(\mathrm{g}_{\text {cat }} \cdot \mathrm{h}\right)$.

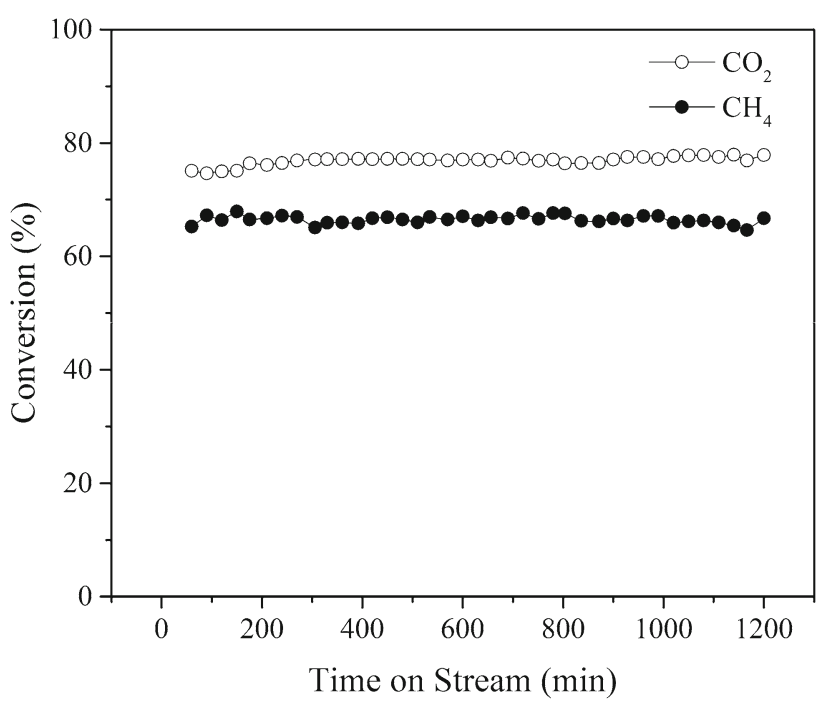

Figure 6. Long-term stability of the optimal $10 \mathrm{Ni} 3 \mathrm{Mn} / \mathrm{Al}_{2} \mathrm{O}_{3}$ catalyst, $\mathrm{CH}_{4}: \mathrm{CO}_{2}=1: 1, \mathrm{~T}=700{ }^{\circ} \mathrm{C}$ and $\mathrm{GHSV}=12000 \mathrm{~mL} /\left(\mathrm{g}_{\text {cat }} \cdot \mathrm{h}\right)$. 

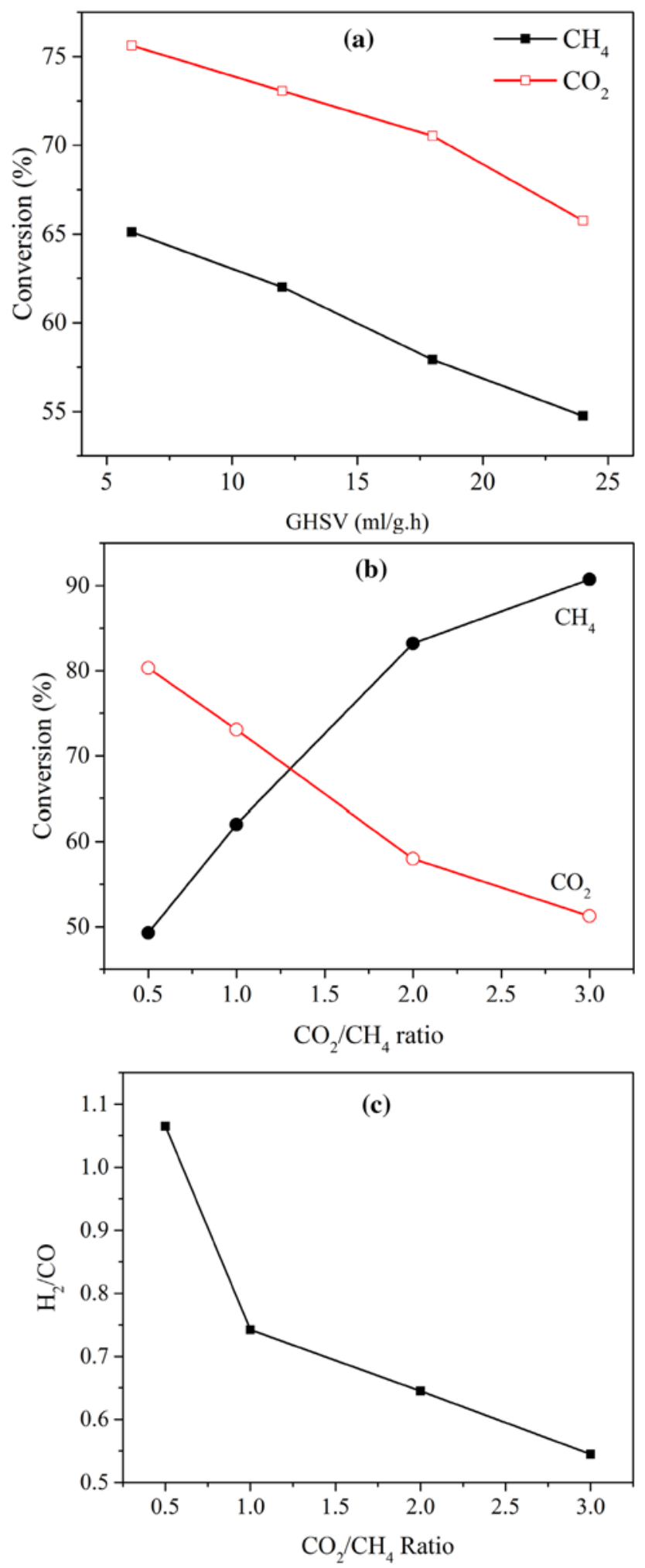

Figure 7. (a) Effect of GHSV, (b) effect of feed ratio on the catalytic activity, and (c) effect of feed ratio on the catalytic performance of $10 \mathrm{Ni}-3 \mathrm{Mn} / \mathrm{Al}_{2} \mathrm{O}_{3}$. Reaction condition: $\mathrm{T}=700{ }^{\circ} \mathrm{C}$.

stronger interaction of $\mathrm{NiO}$ with the support. So by increasing the dispersion of nickel and due to reaction mechanism, obviously the conversion of methane in the

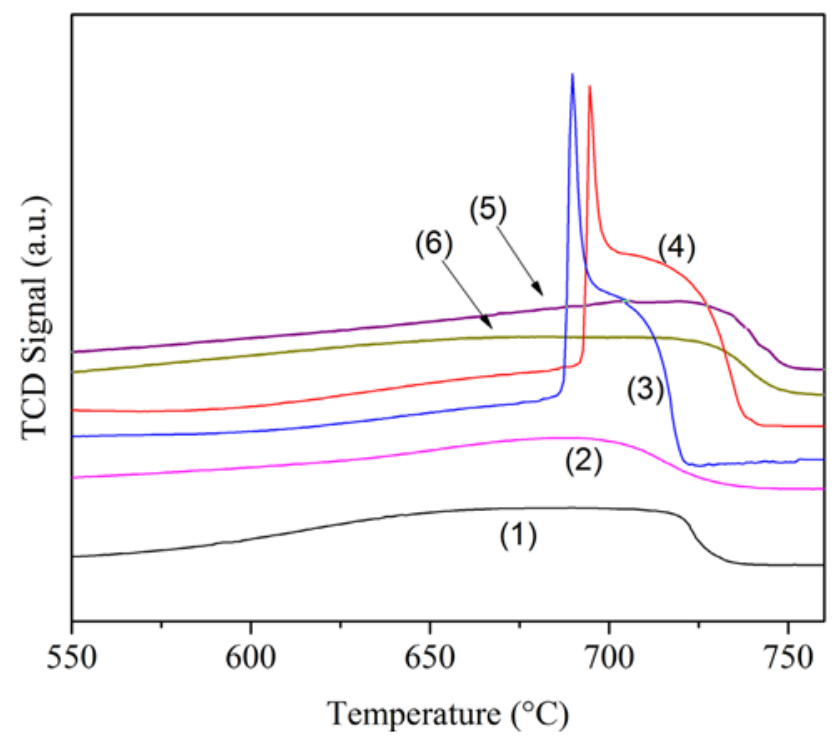

Figure 8. TPO profiles of $\mathrm{Ni}-\mathrm{Mn} / \mathrm{Al}_{2} \mathrm{O}_{3}$ catalysts with different loadings; (1) $10 \mathrm{Ni}$, (2) $10 \mathrm{Ni} 2.5 \mathrm{Mn}$, (3) $10 \mathrm{Ni} 8 \mathrm{Mn}$, (4) $10 \mathrm{Ni} 1 \mathrm{Mn},(5)$ 10Ni3Mn and (6) $10 \mathrm{Ni} 5 \mathrm{Mn}$.

case of the bimetallic catalyst is higher than the single mode. ${ }^{10}$

Since the manganese applies only structural changes in the catalyst and is not an active metal so the $5 \mathrm{Mn}$ catalyst did not show a high catalytic activity. In addition, the catalytic activity of the promoted catalysts with different Mn contents is very close together.

The catalysts were exposed to the reaction atmosphere for $300 \mathrm{~min}$ at $700{ }^{\circ} \mathrm{C}$ to study the catalytic stability of the prepared catalysts. The results showed that all the catalysts had a very high stability without decreasing in $\mathrm{CH}_{4}$ conversion over the test period of $300 \mathrm{~min}$, Figure 5a. Long-term stability the optimal $10 \mathrm{Ni} 3 \mathrm{Mn} / \mathrm{Al}_{2} \mathrm{O}_{3}$ catalyst was performed (Figure $5 \mathrm{~b}$ ).

The results representing the high stability of this catalyst during $20 \mathrm{~h}$ time on-stream under the reaction conditions (Figure 6).

GHSV is one the most important process parameters that affect the catalyst performance. With the increase in GHSV, the residence time of reactants on the catalyst decreases and causes a decrease in conversion of reactants (Figure 7a).

The effect of feed ratio on the catalytic performance of $10 \mathrm{Ni} 3 \mathrm{Mn} / \mathrm{Al}_{2} \mathrm{O}_{3}$ catalyst at $700{ }^{\circ} \mathrm{C}$ is plotted in Figure $7 \mathrm{~b}$. The acquired results show that with the increase in the $\mathrm{CO}_{2} / \mathrm{CH}_{4}$ ratio, the $\mathrm{CH}_{4}$ conversion increased, whereas the $\mathrm{CO}_{2}$ conversion decreased, due to the presence of excess $\mathrm{CO}_{2}$ in the main reaction (1). As previously mentioned, the excess $\mathrm{CO}_{2}$ in this reaction increased the rate of RWGS reaction, which led to a decrease in $\mathrm{H}_{2} / \mathrm{CO}$ ratio, Figure $7 \mathrm{c} .{ }^{34}$ 

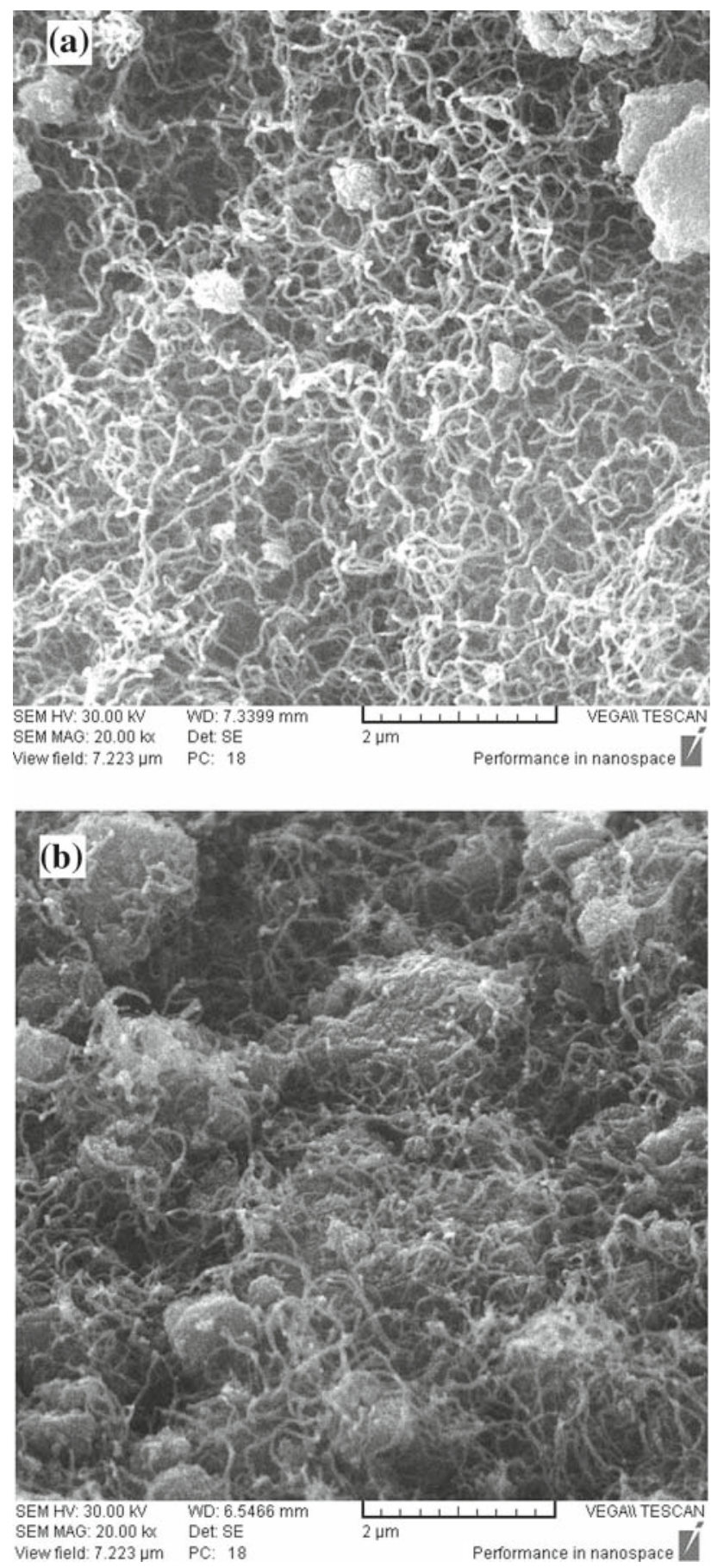

Figure 9. SEM images of (a) $10 \mathrm{Ni} / \mathrm{Al}_{2} \mathrm{O}_{3}$, and (b) $10 \mathrm{Ni} 3 \mathrm{Mn} / \mathrm{Al}_{2} \mathrm{O}_{3}$. Reaction conditions: $\mathrm{CH}_{4} / \mathrm{CO}_{2}=1$, $\mathrm{GHSV}=12000 \mathrm{~mL} /\left(\mathrm{g}_{\text {cat }} \cdot \mathrm{h}\right)$, time on the stream $=300 \mathrm{~min}$.

The substantial purpose of working on an extra metal besides the nickel is to suspend the coke formation. Therefore, to evaluate the impressment of the manganese as a second metal, the TPO analysis was done. ${ }^{35}$ Temperature-programmed oxidation patterns of the spent catalysts are represented in Figure 8. All the samples have one oxidation peak which indicates the type of formed carbon in the process of dry reforming of methane. The peak at approximately $700{ }^{\circ} \mathrm{C}$ can be related to the filamentous form of carbon. Other species such as activated carbon and amorphous carbon are formed at lower temperatures and have not been observed in the TPO profiles of these catalysts. ${ }^{7,9}$

Figure $9 \mathrm{a}$ and $\mathrm{b}$ shows the SEM images of the spent $10 \mathrm{Ni} / \mathrm{Al}_{2} \mathrm{O}_{3}$ and $10 \mathrm{Ni} 3 \mathrm{Mn} / \mathrm{Al}_{2} \mathrm{O}_{3}$, respectively. In both the samples, the whisker-type carbon was observed. However, the SEM analysis showed that the promoted catalyst with $3 \mathrm{wt} \% \mathrm{Mn}$ exhibited a lower degree of carbon formation compared to the unpromoted catalyst, which is in agreement with TPO analysis. ${ }^{7,9,18,28}$

\section{Conclusions}

The Ni-Mn $/ \mathrm{Al}_{2} \mathrm{O}_{3}$ bimetallic catalysts with different loadings of $\mathrm{Mn}$ were prepared and employed in the dry reforming reaction. The results showed that the bimetallic catalysts exhibited higher activity and stability with no severe coke deposition compared with the monometallic sample.

The results indicate that the $10 \mathrm{Ni} 3 \mathrm{Mn} / \mathrm{Al}_{2} \mathrm{O}_{3}$ catalyst was the optimal catalyst among the prepared catalysts. According to the XRD patterns, the addition of $\mathrm{Mn}$ promoter caused a decrease in the intensity of $\mathrm{NiO}$ and $\mathrm{NiAl}_{2} \mathrm{O}_{4}$ diffraction patterns, indicating that $\mathrm{Mn}$ improves the dispersion of the active metal species in the catalyst or incorporates into the support due to a decrease in the crystallite size of $\mathrm{Ni}$ and consequently causes an increase in $\mathrm{Ni}$ dispersion.

With the increase in GHSV, the residence time of reactants on the catalyst decreases and causes a decrease in conversion of reactants. The acquired results show that with the increase in the $\mathrm{CO}_{2} / \mathrm{CH}_{4}$ ratio, the $\mathrm{CH}_{4}$ conversion increased, whereas the $\mathrm{CO}_{2}$ conversion decreased, due to the presence of excess $\mathrm{CO}_{2}$ in the main reaction. The SEM analysis showed that the promoted catalyst with $3 \mathrm{wt} \%$ Mn exhibited a lower degree of carbon formation compared to unpromoted catalyst.

\section{Acknowledgements}

The authors gratefully acknowledge the support from the University of Kashan for supporting this work by Grant No. 682704/3.

\section{References}

1. Özkara-Aydınoğlu Ş and Aksoylu A E 2010 Carbon dioxide reforming of methane over $\mathrm{Co}-\mathrm{X} / \mathrm{ZrO}_{2}$ catalysts (X= La, Ce, Mn, Mg, K) Catal. Commun. 111165 
2. Koubaissy B, Pietraszek A, Roger A and Kiennemann A $2010 \mathrm{CO}_{2}$ reforming of methane over $\mathrm{Ce}-\mathrm{Zr}-\mathrm{Ni}-\mathrm{Me}$ mixed catalysts Catal. Today $\mathbf{1 5 7} 436$

3. Asencios Y J and Assaf E M 2013 Combination of dry reforming and partial oxidation of methane on $\mathrm{NiO}-\mathrm{MgO}-\mathrm{ZrO}_{2}$ catalyst: effect of nickel content Fuel Process. Technol. 106247

4. Khalesi A, Arandiyan H R and Parvari M 2008 Effects of lanthanum substitution by strontium and calcium in La-Ni-Al perovskite oxides in dry reforming of methane Chin. J. Catal. 29960

5. Hou Z, Chen P, Fang H, Zheng $X$ and Yashima T 2006 Production of synthesis gas via methane reforming with $\mathrm{CO}_{2}$ on noble metals and small amount of noble (Rh) promoted Ni catalysts Int. J. Hydrogen Energy 31 555

6. Shi C and Zhang P 2012 Effect of a second metal (Y, K, $\mathrm{Ca}, \mathrm{Mn}$ or $\mathrm{Cu}$ ) addition on the carbon dioxide reforming of methane over nanostructured palladium catalysts Appl. Catal. B 115190

7. Alipour Z, Rezaei M and Meshkani F 2014 Effect of Ni loadings on the activity and coke formation of $\mathrm{MgO}$ modified $\mathrm{Ni} / \mathrm{Al}_{2} \mathrm{O}_{3}$ nanocatalyst in dry reforming of methane J. Energy Chem. 23633

8. Arandiyan H, Li J, Ma L, Hashemnejad S, Mirzaei M, Chen J, Chang H, Liu C, Wang C and Chen L 2012 Methane reforming to syngas over $\mathrm{LaNi}_{\mathrm{x}} \mathrm{Fe}_{1-\mathrm{x}} \mathrm{O}_{3}(0 \leq$ $\mathrm{x} \leq 1$ ) mixed-oxide perovskites in the presence of $\mathrm{CO}_{2}$ and $\mathrm{O}_{2}$ J. Ind. Eng. Chem. 182103

9. Alipour Z, Rezaei M and Meshkani F 2014 Effect of alkaline earth promoters $(\mathrm{MgO}, \mathrm{CaO}$, and $\mathrm{BaO})$ on the activity and coke formation of $\mathrm{Ni}$ catalysts supported on nanocrystalline $\mathrm{Al}_{2} \mathrm{O}_{3}$ in dry reforming of methane $J$. Ind. Eng. Chem. 20633

10. Yao L, Zhu J, Peng X, Tong D and Hu C 2013 Comparative study on the promotion effect of $\mathrm{Mn}$ and $\mathrm{Zr}$ on the stability of $\mathrm{Ni} / \mathrm{SiO}_{2}$ catalyst for $\mathrm{CO}_{2}$ reforming of methane Int. J. Hydrogen Energy 387268

11. Huang T, Huang W, Huang J and Ji P 2011 Methane reforming reaction with carbon dioxide over SBA-15 supported Ni-Mo bimetallic catalysts Fuel Process. Technol. 921868

12. Quincoces C E, de Vargas S P, Grange P and González M G 2002 Role of Mo in $\mathrm{CO}_{2}$ reforming of $\mathrm{CH}_{4}$ over Mo promoted $\mathrm{Ni} / \mathrm{Al}_{2} \mathrm{O}_{3}$ catalysts Mater. Lett. 56 698

13. Kathiraser Y, Oemar U, Saw E T, Li Z and Kawi S 2015 Kinetic and mechanistic aspects for $\mathrm{CO}_{2}$ reforming of methane over $\mathrm{Ni}$ based catalysts Chem. Eng. J. 278 62

14. Meshkani F and Rezaei M 2010 Nanocrystalline MgO supported nickel-based bimetallic catalysts for carbon dioxide reforming of methane Int. J. Hydrogen Energy 3510295

15. Rezaei M, Alavi S M, Sahebdelfar S and Yan Z-F 2006 Nanocrystalline zirconia as support for nickel catalyst in methane reforming with $\mathrm{CO}_{2}$ Energy Fuel 20 923

16. Meshkani F and Rezaei M 2015 Preparation of mesoporous nanocrystalline iron based catalysts for high temperature water gas shift reaction: effect of preparation factors Chem. Eng. J. 260107
17. Zhang J, Wang H and Dalai A K 2007 Development of stable bimetallic catalysts for carbon dioxide reforming of methane J. Catal. 249300

18. Long $\mathrm{H}, \mathrm{Xu} \mathrm{Y}$, Zhang X, Hu S, Shang S, Yin Y and Dai X 2013 Ni-Co/Mg-Al catalyst derived from hydrotalcitelike compound prepared by plasma for dry reforming of methane J. Energy Chem. 22733

19. de Abreu A J, Lucrédio A F and Assaf E M $2012 \mathrm{Ni}$ catalyst on mixed support of $\mathrm{CeO}_{2}-\mathrm{ZrO}_{2}$ and $\mathrm{Al}_{2} \mathrm{O}_{3}$ : effect of composition of $\mathrm{CeO}_{2}-\mathrm{ZrO}_{2}$ solid solution on the methane steam reforming reaction Fuel Process. Technol. 102140

20. Djaidja A, Messaoudi H, Kaddeche D and Barama A 2015 Study of $\mathrm{Ni}-\mathrm{M} / \mathrm{MgO}$ and $\mathrm{Ni}-\mathrm{M}-\mathrm{Mg} / \mathrm{Al}(\mathrm{M}=\mathrm{Fe}$ or $\mathrm{Cu}$ ) catalysts in the $\mathrm{CH}_{4}-\mathrm{CO}_{2}$ and $\mathrm{CH}_{4}-\mathrm{H}_{2} \mathrm{O}$ reforming Int. J. Hydrogen Energy 404989

21. Chen L, Zhu Q, Hao Z, Zhang T and Xie Z 2010 Development of a Co-Ni bimetallic aerogel catalyst for hydrogen production via methane oxidative $\mathrm{CO}_{2}$ reforming in a magnetic assisted fluidized bed Int. J. Hydrogen Energy 358494

22. Chen L, Zhu Q, Hao Z, Zhang T and Xie Z 2010 Development of a Co-Ni bimetallic aerogel catalyst for hydrogen production via methane oxidative $\mathrm{CO}_{2}$ reforming in a magnetic assisted fluidized bed Int. J. Hydrogen Energy 358494

23. Choi J S, Moon K I, Kim Y G, Lee J S, Kim C H and Trimm D L 1998 Stable carbon dioxide reforming of methane over modified $\mathrm{Ni} / \mathrm{Al}_{2} \mathrm{O}_{3}$ catalysts Catal. Lett. 5243

24. Seok S H, Choi S H, Park E D, Han S H and Lee J S $2002 \mathrm{Mn}$-promoted $\mathrm{Ni} / \mathrm{Al}_{2} \mathrm{O}_{3}$ catalysts for stable carbon dioxide reforming of methane J. Catal. 2096

25. Borowiecki T, Gac W and Denis A 2004 Effects of small $\mathrm{MoO}_{3}$ additions on the properties of nickel catalysts for the steam reforming of hydrocarbons: III. Reduction of Ni-Mo/ $\mathrm{Al}_{2} \mathrm{O}_{3}$ catalysts Appl. Catal. A 270 27

26. Son I H, Lee S J, Song I Y, Jeon W S, Jung I, Yun D J, Jeong D W, Shim J O Jang W J and Roh H S 2014 Study on coke formation over $\mathrm{Ni} / \gamma-\mathrm{Al}_{2} \mathrm{O}_{3}, \mathrm{Co}-\mathrm{Ni} / \gamma-\mathrm{Al}_{2} \mathrm{O}_{3}$, and $\mathrm{Mg}-\mathrm{Co}-\mathrm{Ni} / \gamma-\mathrm{Al}_{2} \mathrm{O}_{3}$ catalysts for carbon dioxide reforming of methane Fuel 136194

27. Huang L, Zhang F, Chen $\mathrm{R}$ and Hsu A T 2012 Manganese-promoted nickel/alumina catalysts for hydrogen production via auto-thermal reforming of ethanol Int. J. Hydrogen Energy 3715908

28. Meshkani F and Rezaei M 2011 Nickel catalyst supported on magnesium oxide with high surface area and plate-like shape: a highly stable and active catalyst in methane reforming with carbon dioxide Catal. Commun. 121046

29. Leofanti G, Padovan M, Tozzola G and Venturelli B 1998 Surface area and pore texture of catalysts Catal. Today 41207

30. Ay H and Üner D 2015 Dry reforming of methane over $\mathrm{CeO}_{2}$ supported Ni, $\mathrm{Co}$ and $\mathrm{Ni}-\mathrm{Co}$ catalysts Appl. Catal. B 179128

31. Rahmani S, Rezaei M and Meshkani F 2014 Preparation of highly active nickel catalysts supported on mesoporous nanocrystalline $\gamma-\mathrm{Al}_{2} \mathrm{O}_{3}$ for $\mathrm{CO}_{2}$ methanation J. Ind. Eng. Chem. 201346 
32. Bhavani A G, Kim W Y, Kim J Y and Lee J S 2013 Improved activity and coke resistance by promoters of nanosized trimetallic catalysts for autothermal carbon dioxide reforming of methane Appl. Catal. A 45063

33. Siahvashi A, Chesterfield D and Adesina A A 2013 Propane $\mathrm{CO}_{2}$ (dry) reforming over bimetallic Mo-Ni/Al ${ }_{2} \mathrm{O}_{3}$ catalyst Chem. Eng. Sci. 93313
34. Usman M, Daud W W and Abbas H F 2015 Dry reforming of methane: influence of process parameters-a review Renew. Sust. Energ. Rev. 45710

35. Al-Fatesh A 2015 Suppression of carbon formation in $\mathrm{CH}_{4}-\mathrm{CO}_{2}$ reforming by addition of $\mathrm{Sr}$ into bimetallic $\mathrm{Ni}-\mathrm{Co} / \gamma-\mathrm{Al}_{2} \mathrm{O}_{3}$ catalyst J. King Saud. Univ. Eng. Sci. 27101 